\title{
Examining Life Satisfaction Levels of Teachers Working in Special Education Institutions in Terms of Some Variables
}

\author{
Mehmet Yavuz ${ }^{1}$, Ahmet Yikmiş ${ }^{2}$ \\ ${ }^{1}$ Department of Special Education, Faculty of Education, Trakya University, Turkey \\ ${ }^{2}$ Department of Special Education, Faculty of Education, Bolu Abant İzzet Baysal University \\ Correspondence: Mehmet Yavuz, Department of Special Education, Faculty of Education, Trakya University, Turkey.
}

Received: August 18, 2019

doi:10.11114/jets.v7i11.4460
Accepted: October 2, $2019 \quad$ Online Published: October 8, 2019

URL: https://doi.org/10.11114/jets.v7i11.4460

\begin{abstract}
This study aims to examine life satisfaction levels of teachers working in special education institutions in terms of some variables. The study was carried out with 378 teachers working in 18 special education schools of Istanbul Provincial Directorate of National Education in 2017-2018 Academic Year. Survey model was used in the study. In order to collect the data, Satisfaction with Life Scale, which was developed by Diener, Emmons, Larsen and Griffin (1985), and which was adapted into Turkish by Dağlı and Baysal (2016), were used. Data were analyzed with SPSS program and T-Test and One-Way Anova were applied. According to the results of the study, a significant difference was revealed in favor of female teachers in terms of gender; and in terms of branch variable in favor of the teachers who were graduated from special education field. No significant differences were observed in terms of the support received from colleagues, the support received from managers, salary and age variables.
\end{abstract}

Keywords: special education, life satisfaction, special education teachers

\section{Introduction}

Life satisfaction, which was first proposed by Neugarten in 1961, is defined as positive perception of the whole life in line with the criteria that are determined by the individual (Veenhoven, 1996). In other words, it is defined as the result of comparison of the expectations of the individual with existing conditions (Ozer and Karabulut, 2003; Veenhoven, 1996). This situation is that the individual feels cognitively good as a result of his/her subjective evaluations. In other words, life satisfaction is a subjective evaluation. Subjective well-being, on the other hand, is the result of the evaluation of the individual about his/her life from both cognitive and emotional dimensions (Diener, 1984). According to Ozer and Karabulut (2003), individuals who have high life satisfaction levels consider themselves as valuable, enjoy every activity they do, and look at life in a positive way. When considered in this respect, life satisfaction is the most important determinant of the overall happiness of an individual (Diener, Emmons, Larsen, and Griffin, 1985). According to Ucuncu (2019), life satisfaction is the result of Maslow's need hierarchy for self-fulfillment of an individual. The achievement of an individual in terms of life satisfaction is to reach the end-point by using all his/her potential, ability and knowledge. When the individual realizes himself/herself, he or she will not feel any deficiencies and will reach happiness. The life satisfaction perception of an individual is affected by several variables. These variables are professional burnout, stress, psychological and physical well-being, job satisfaction and motivation, self-efficacy, self-esteem, and positive personal opinions about life (Hakanen, Bakker and Schaufeli, 2006, Tsouloupas, Carson, Matthews, Grawitch and Barber, 2010).

Special education field is more difficult than other education fields since developmental characteristics of children with disabilities are different from others, there is a difficulty in controlling them because of behavioral and communicational problems, a difficulty in teaching new behaviors to these students, and because of professional dissatisfaction (Sucuoglu and Kuloglu, 1996). According to Basaran (2001), it is very difficult to control individuals with disabilities and there are several problems in the education of these children. For this reason, teachers who work in these schools are not satisfied with their conditions and therefore, teachers who work with individuals with disabilities are stressful (Girgin and Baysal, 2005). Because of these factors, teachers who work in special education schools have more burnout feelings (Girgin and Baysal, 2005; Sucuoglu and Kuloglu, 1996).

In respect to all these mentioned reasons, it is important that teachers working in special education schools have high life satisfaction levels since teachers with high life satisfaction levels are concerned with their students in a better manner 
(Hargreaves, 2000). In addition, since teachers are at a position that will influence social and academic lives of students positively in school lives, they will also affect students positively in their social and academic lives (Roth, Assor, Kanat-Maymon and Kaplan, 2007). Life satisfaction levels of teachers contributes positively to their individual and professional developments (O'Connor, 2008). First of all, it helps teacher to achieve better levels in his/her career. This brings professional satisfaction and prevents them from leaving their professions (van Veen, Sleegers and van de Ven, 2005). Life satisfaction levels of teachers will also affect the school positively and ensure a stable and positive environment in the school. However, a teacher who has low life satisfaction will have a negative effect on the school environment and will have a negative effect on the national economy if he or she leaves the profession (Roffey, 2012).

When the literature is examined, it is seen that there is limited number of studies carried out on the life satisfaction levels of special education teachers (Aydemir et al., 2015; Isiktas, 2016; Y1lmaz and Uredi, 2018; Karabas and Ciftci, 2019). Since special education field is a difficult field, life satisfaction levels of teachers working in this field must be high. The limited number of the studies on life satisfaction of teachers in special education field revealed the necessity of conducting this study. In addition, if teachers in special education field have better life satisfaction levels, this will contribute to their development. For this reason, this study aims to examine life satisfaction levels of teachers working in special education institutions in terms of some variables. In line with this aim, the answers to the following questions were sought:

1. Do the life satisfaction levels of teachers working in special education field show a significant difference in terms of gender?

2. Do the life satisfaction levels of teachers working in special education field show a significant difference in terms of the salary?

3. Do the life satisfaction levels of teachers working in special education field show a significant difference in terms of the support received from colleagues?

4. Do the life satisfaction levels of teachers working in special education field show a significant difference in terms of the support received from managers?

5. Do the life satisfaction levels of teachers working in special education field show a significant difference in terms of the age?

6. Do the life satisfaction levels of teachers working in special education field show a significant difference in terms of the field of graduation?

\section{Method}

Survey model was used in the study. Survey models constitute an approach which aims to explain a situation that has happened in the past or in the present and individuals or the objects that are the subject matters of the study as they are in their own conditions (Karasar, 1984).

\subsection{Participants}

The participants of the study consisted of the 378 teachers working in 18 schools in special education institutions of Istanbul Provincial Directorate of National Education in 2017-2018 Academic Year. The demographic characteristics of the participants are shown in Table 1.

Table 1. Demographical characteristics of teachers

\begin{tabular}{|c|c|c|c|c|c|}
\hline Gender & $\mathrm{N}$ & $\%$ & Is your salary adequate? & $\mathrm{N}$ & $\%$ \\
\hline Male & 179 & 47.35 & Yes & 53 & 14.02 \\
\hline Female & 199 & 52,65 & No & 325 & 85.98 \\
\hline $\begin{array}{l}\text { Do you receive support from your } \\
\text { colleagues? }\end{array}$ & $\mathrm{N}$ & $\%$ & Are you admired by the managers? & $N$ & $\%$ \\
\hline 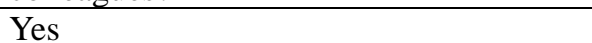 & 346 & 91.53 & Yes & 289 & 76.45 \\
\hline No & 32 & 8,47 & No & 89 & 23,55 \\
\hline Age & $\mathrm{N}$ & $\%$ & Your branch & & \\
\hline Below 30 & 210 & 55.55 & Special education & 50 & 13.22 \\
\hline $31-40$ & 108 & 28.57 & Other & 328 & 86.88 \\
\hline Over 40 & 60 & 15.88 & & & \\
\hline
\end{tabular}

As it can be seen in Table 1, a total number of 378 teachers participated in the study. A total number of 179 of the teachers participated in the study were male $(47.35 \%)$, and $199(52.65 \%)$ were female, $53(14.02 \%)$ considered their salary as sufficient, $325(85.98 \%)$ did not see the salary as sufficient, $346(91.53 \%)$ received support from colleagues, $32(8.47 \%)$ did not receive support from colleagues, $289(76.45 \%)$ were appreciated by the managers, $89(23.55 \%)$ were not appreciated by the managers, $210(55.55 \%)$ were under the age of 30, 108 (28.57\%) were between the ages of 31-40, 60 
(15.88\%) were over the age of 40, 50 (13.22) were graduates of Special Education, and 328 (86.88\%) were graduates from other fields.

\subsection{Data Collection Tools}

\subsubsection{Demographical Information Form}

The Demographic Information Form was developed by the first researcher. During the development process of the form, literature review was carried out and a draft form was created. Then, expert opinions were received from 1 associate professor and 2 doctors as faculty members from special education field. Gender, whether the salary was sufficient, whether teachers were supported by colleagues, whether they were supported by managers, age and branch data were included in the form.

\subsubsection{Life Satisfaction Scale}

Life Satisfaction Scale was developed by Diener, Emmons, Larsen and Griffin (1985) and was adapted into Turkish by Dagli and Baysal (2016) by conducting its validity and reliability study. The scale is one-dimensional, 5-point Likert-Type scale and it includes 5 items. The Cronbach's Alpha Coefficient of the scale was 0.88 and test-retest reliability was 0.97.

\subsection{Data Collection}

In order to collect the data, researchers went to special education schools. The purpose of the study was explained to the teachers who volunteered to participate in the study. They were also told how to fill in the scale. A total number of 460 scales were distributed and 382 scales were collected. As a result of the analyses, it was determined that 378 scales were filled in correctly and the data in 378 scales were analyzed.

\subsection{Data Analysis}

SPSS 22.0 program was used for the data analyses. The normality test was applied to the data and the Kurtosis and Skewness values of the data were also examined. As Tabachnick and Fidell (2013) stated about Kurtosis and Skewness values, "If the Kurtosis and Skewness are between +1.5 and -1.5 , they are considered normally distributed". As a result of the normality test, it was determined that life satisfaction data showed normal distribution. For this reason, T-test and One-Way Anova were used for data analysis.

\section{Results}

In this section, gender, whether the salary was sufficient, whether teachers were supported by colleagues, whether they were supported by managers, age, and branch data are be included.

Table 2. T-test results of teachers for life satisfaction levels in terms of gender variable

\begin{tabular}{cccccccc}
\hline & Gender & $N$ & $\bar{x}$ & $S D$ & $\mathrm{t}$ & $\mathrm{df}$ & $\mathrm{p}$ \\
\hline \multirow{2}{*}{ Life satisfaction } & Male & 179 & 2,502 &, 891 & \multirow{2}{*}{224} & 366 &, 000 \\
& Female & 199 & 2,913 &, 954 & & &
\end{tabular}

As it is seen in Table 2, life satisfaction levels of teachers showed a significant difference in terms of gender $(\mathrm{t}=.000$; $\mathrm{p}<0.05$ ). Significant differences were revealed in favor of female teachers (Female $=2.913$; Male $=2.502$ ) according to the overall score of the scale.

Table 3. T-test results of life satisfaction levels of teachers in terms of salary variable

\begin{tabular}{cccccccc}
\hline & Salary & $N$ & $\bar{x}$ & $S D$ & $\mathrm{t}$ & $\mathrm{df}$ & $\mathrm{p}$ \\
\hline \multirow{2}{*}{ Life satisfaction } & Yes & 53 & 2,850 &, 951 & 366 & \multirow{2}{*}{, 559} &,- 084 \\
& No & 325 & 2,934 &, 920 & & &
\end{tabular}

As it can be seen in Table 3, life satisfaction levels of the teachers did not show significant differences in terms of salaries $(\mathrm{t}=.084 ; \mathrm{p}>0.05)$.

Table 4. T-test results of life satisfaction level of teachers in terms of receiving support from colleagues variable

\begin{tabular}{cccccccc}
\hline & $\begin{array}{c}\text { 2eceiving support fron } \\
\text { colleagues variable }\end{array}$ & $N$ & $\bar{x}$ & $S D$ & $\mathrm{t}$ & $\mathrm{df}$ & $\mathrm{p}$ \\
\hline \multirow{2}{*}{ Life satisfaction } & Yes & 346 & 2,931 &, 929 &, 631 & 366 &, 528 \\
& No & 32 & 2,815 &, 861 & & & \\
\hline
\end{tabular}


As it can be seen in Table 4, there were no significant differences in terms of receiving support from colleagues variable $(\mathrm{t}=.528 ; \mathrm{p}>0.05)$.

Table 5. T-test results of life satisfaction level of teachers in terms of receiving support from managers variable

\begin{tabular}{cccccccc}
\hline & $\begin{array}{c}\text { Receiving support from } \\
\text { managers }\end{array}$ & $N$ & $\bar{x}$ & $S D$ & $\mathrm{t}$ & $\mathrm{df}$ & $\mathrm{p}$ \\
\hline \multirow{2}{*}{ Life satisfaction } & Yes & 289 & 2,939 &, 942 &, 607 & 366 &, 544 \\
& No & 89 & 2,869 &, 858 & & &
\end{tabular}

As it can be seen in Table 5, there were no differences in terms of receiving support from managers $(\mathrm{t}=.544 ; \mathrm{p}>0.05)$.

Table 6. T-test results of life satisfaction level of teachers in terms of age variable

\begin{tabular}{ccccccc}
\hline & Age & $N$ & $\bar{x}$ & $S D$ & $\mathrm{f}$ & $\mathrm{p}$ \\
\hline \multirow{3}{*}{ Life satisfaction } & Below 30 & 210 & 2,927 &, 974 & 1,699 &, 184 \\
& Between 31 and 40 & 108 & 2,819 &, 877 & & \\
& Over 40 & 60 & 3,097 &, 798 & & \\
\hline
\end{tabular}

As it can be seen in Table 6 , there were no significant differences in terms of the age variable $(\mathrm{t}=.184 ; \mathrm{p}>0.05)$.

Table 7. T-test results of life satisfaction level of teachers in terms of the school graduated variable

\begin{tabular}{cccccccc}
\hline & Graduation & $N$ & $\bar{x}$ & $S D$ & $\mathrm{t}$ & $\mathrm{df}$ & $\mathrm{p}$ \\
\hline \multirow{3}{*}{ Life satisfaction } & Special education & 50 & 2,996 &, 925 &, 564 & 366 & \multirow{2}{*}{, 003} \\
& Other & 328 & 2,513 &, 904 & & &
\end{tabular}

As it can be seen in Table 7, results showed significant difference in terms of the field the teachers graduated from ( $\mathrm{t}=.003$; $\mathrm{p}<0.05)$. According to the overall score of the scale, there was a significant difference in favor of the teachers who graduated from special education field (Special education:=2.996; Other:=2.513).

\section{Discussion}

Life satisfaction levels of teachers working in special education schools showed a significant difference in terms of gender variable in favor of female teachers. When the literature is examined, it is seen that there are similar findings. In their study conducted with special education teachers, Aydemir, Diken, Demirtas, Aksoy, Ozokcu (2015), Demirel (2014) and Karabas and Ciftci (2019) reported that female teachers had higher life satisfaction levels. However, Isiktas (2016) did not report a significant relation between life satisfaction levels of female and male teachers in the study conducted with special education teachers. Muthamizhselvan and Kumar (2017) carried out a study with secondary school teachers and reported no significant relation between female and male teachers. Similarly, Kumar (2014) did not reveal any significant differences in terms of gender variable in the study conducted with primary and secondary school teachers. In their study which examined the relations between job and life satisfaction with pre-school, primary school, culture lesson teachers and vocational high school teachers, Aydintan and Koc (2016) reported that females scored higher in the relations between job and life satisfaction levels in terms of gender variable. Aydintan and Koc (2016) stated that job satisfaction levels of male teachers had a significant effect on the life satisfaction levels.

No significant differences were observed in terms of salary variable of teachers working in special education schools. There are contradictory findings in the literature about these findings. According to Keser (2003), satisfaction of the employee with salary contributed to life satisfaction positively. Avsaroglu, Deniz and Kahraman (2005), Cecen, Rezan and Orkun (2012), Musal, Elci and Ergin (1995) and Paolini, Yanez and Kelly (2006) reported that salary variable was effective on life satisfaction. In addition, Atakli, Dikmentas and Altinisik (2004) conducted a study with university hospital staff and reported that salary was among the variables that affected job satisfaction levels at the highest level. Ucuncu (2019) conducted a study with primary and secondary school teachers and concluded that teachers who found their salary sufficient had higher life satisfactions. According to Yilmaz and Sunbul (2009), these perceptions of the employees influence their life perception and therefore, their life satisfaction as well. When these aspects are considered, it is effective to receive a satisfactory salary from the work done among the factors that affect life satisfaction. According 
to the results of this study, the reason for not finding a significant difference in terms of the salary variable may be because of the fact that special education field is a field that requires sacrifice. Teachers working in this field may have selected their jobs without considering the salary variable in the first place.

No significant differences were detected in the support received from colleagues of teachers working in special education schools. According to Oshagbemi (2000), the relations of teachers with school employees are very important. Special education teachers are in a close relation with the school staff, which could be good aspect. Ucuncu (2019) reported negative interpersonal relations with colleagues is another reason for dissatisfaction with the job and weak or unsupportive relations and conflicts with other colleagues or supervisors may result in poor job satisfaction. Having good relations with colleagues means receiving support from them. Receiving enough support from colleagues will help solving problems that are caused by school students and parents. Failure in receiving sufficient support from colleagues might cause professional burnout, stress and tension throughout the day (Kaner, Sekercioglu, \& Yellice-Yuksel 2007). Since work life is one of the factors that affect life satisfaction, having problems with colleagues and not receiving adequate support from them might affect life satisfaction of teachers negatively.

No significant differences were observed in the support of managers variable of teachers working in special education schools. When the literature is examined, it is seen that appreciation of the managers contributes positively to job satisfaction (Robbins, 1996). In parallel with this, Wangari and Orodho (2014) conducted a study with special education teachers and reported that teachers who were admired by their managers had higher job satisfaction levels. According to the Life Satisfaction and Components Model of Near, Rice and Hunt (1978), job satisfaction is one of the factors that affect the life satisfaction. According to this model, as the job satisfaction of teachers who receive appreciation from their administrators increases, and naturally, their life satisfaction will also increase. For this reason, according to Keser (2003), businesses can increase life satisfaction levels of their employees by giving importance to employee satisfaction.

No significant differences were detected in the age variable of teachers working in special education schools. According to literature, there are studies showing that age variable is effective on life satisfaction. Gulcan (2014) reported that age variable was an important variable for life satisfaction. Aydemir, Diken, Demirtas, Aksoy, Ozokcu (2015) conducted a study with special education teachers and reported that life satisfaction decreases as the age progresses. Sahin (2008) carried out a study with physical education teachers and reported a positive relation between personal achievement which is the sub-dimension of burnout scale and life satisfaction. Sahin (2008) interpreted this situation as the increase in life satisfaction of teachers who considered themselves as positive and whose perceptions on achievement increased. On the other hand, Sahin (2008) reported that although the first studies found that young people were happier than the elderly, recent studies have shown that there is no relation between happiness and age. This statement is in line with the findings of the present study. A significant difference was detected in the graduation field of teachers working in special education schools. When the literature is examined, it is seen that Isiktas (2016) reported that life satisfaction levels of teachers who were graduated from special education were higher.

In their study, Yilmaz and Uredi (2018) compared job satisfaction levels of teachers who started working in special education after graduating from this field and those who graduated from other schools but started to work in special education by making field changes and did not observe a significant difference in terms of the graduation field variable. Cetin and Sen (2017) conducted a study and reported that teachers who were graduated from other fields and who worked in special education and rehabilitation centers had difficulties in preparing and implementing Individualized Education Programs (IEP), identifying and applying proper teaching methods, material selection, making students acquire and evaluate new behaviors and coping with problem behaviors. Karabas and Ciftci (2019) examined burnout and life satisfaction levels of teachers working in special education field and found that life satisfaction levels of teachers were at moderate level. In addition, it was also concluded that "work-related burnout", which is one of the sub-dimensions of burnout scale, was at the highest level. The justification of this was associated by them with the reasons such as teaching methods, which contain the characteristics of the field, and classroom management in the field of special education. The reason for the high life satisfaction levels of the graduates of special education in this study may be because of the fact that they know special education field and characteristics of the students and that they do not have difficulty in issues about education in this field. Teachers, who work in the field of special education, who know the special education field, and who know the characteristics of these students, who can prepare proper education programs for their students, who can make arrangements in the teaching settings, who can prepare materials that are proper for the learning characteristics of these students, will perform their job in a more qualified manner. Teachers who are happy in their work will have higher life satisfaction levels.

There are certain limitations in this study. This study was limited with the city of Istanbul, teachers who participated in this study and with the life satisfaction scale used in the study. Future studies might use different life satisfaction scales and different sample groups. In addition, life satisfaction levels of teachers might be examined in a detailed way with a mixed research design with Life Satisfaction Scale and Semi-Structured Interview. In order to increase life satisfaction 
levels of teachers, their salaries can be increased. Communication seminars could be organized to increase the individual relations of the teachers. Seminars can be organized to increase the professional knowledge of teachers and to inform them about the new developments in the field of special education.

\section{References}

Akcamete, G., Kaner, S., \& Sucuoglu, B. (2001). Ogretmenlerde tukenmislik, is doyumu ve kisilik, Nobel Yayin Dagitim, Ankara.

Aydemir, H., Diken, I., K., Yikmis, A., Aksoy, V., \& Ozokcu, O. (2015). Ozel egitim alaninda calisan ogretmenlerin tukenmislik duzeyleri ve yasam doyumlarinin incelenmesi. Abant Izzet Baysal Universitesi Egitim Fakultesi Dergisi, 15(Ozel Say1), 68-86. https://doi.org/10.17240/aibuefd.2015.15.0-5000128644

Aydintan, B., \& Koc, H. (2016). The relationship between job satisfaction and life satisfaction: An empirical study on teachers. International Journal of Business and Social Science, 7(10), 72-80.

Cecen, E., Rezan, A., \& Orkun, U. (2012). Tekstil sektoru mavi yaka calisanlarinin yasam doyumu ve tukenmislik duzeylerinin is doyumu tarafindan yordanmasi. Cukurova Universitesi Sosyal Bilimler Enstitusu Dergisi, 21(1), 323-338.

Dagli, A., \& Baysal, N. (2016). Yasam doyumu olceginin Turkce 'ye uyarlanmasi: Gecerlik ve guvenirlik calismasi. Elektronik Sosyal Bilimler Dergisi, 15(59), 1250-1262. https://doi.org/10.17755/esosder.263229

Diener, E. (1984). Subjective well-being. Psychological Buletin, 95(3), 542-575. https://doi.org/10.1037/0033-2909.95.3.542

Diener, E., \& Lucas, R. E. (1999). Subjective well-being: Three decades of progress. Psychological Bulletin, 125(2), 276-303. https://doi.org/10.1037/0033-2909.125.2.276

Diener, E., Emmons, R. A., Larsen, R. J., \& Griffin, S. (1985). The satisfaction with life scale. Journal Personality and Social Psychology, 68, 653-663. https://doi.org/10.1207/s15327752jpa4901_13

Girgin, G., \& Baysal, A. (2006). Zihinsel engelli ogrencilere egitim veren ogretmenlerin mesleki tukenmislik duzeyi ve bazi değiskenler (Izmir ornegi). Pamukkale Universitesi Egitim Fakultesi Dergisi, 18(6), 1-10.

Gulcan, A. (2014). Genc yetiskinlerde iyimserligin mutluluk ve yasam doyumu uzerindeki etkisinin incelenmesi. Fatih Universitesi Sosyal Bilimler Enstitusu, Unpublished master thesis.

Hakanen, J. J., Bakker, A. B., \& Schaufeli, W. B. (2006). Burnout and work engagement among teachers. Journal of School Psychology, 43, 495-513. https://doi.org/10.1016/j.jsp.2005.11.001

Hargreaves, A. (2000). Mixed emotions: Teachers' perceptions of their interactions with students. Teaching and Teacher Education, 16, 811-826. https://doi.org/10.1016/S0742-051X(00)00028-7

Isiktas, S. (2016). Ozel egitim ogretmenlerinin tukenmislik ve yasam doyumlarina iliskin goruslerinin incelenmesi. Turkish Studies, 11(19) 461-476. https://doi.org/10.7827/TurkishStudies.9600

Karasar, N. (1984). Bilimsel arastirma yontemi. Ankara: Hacettepe Tas Kitapcilik.

Keser, A. (2003). Calisma yasaminda motivasyon ve yasam tatmini. Alf Aktuel, Istanbul.

Kumar, M. (2014). Study of life satisfaction among primary, middle and secondary schools teachers of district kathua. International Journal of Research, 1(5), 492-498.

Musal, B., Elci, O. C., \& Ergin, S. (1995). Uzman hekimlerde mesleki doyum. Toplum ve Hekim, 10(68), 2-7.

Muthamizhselvan, M., \& Kumar, L. (2017). Life satisfaction of secondary school teachers. International Journal of Multidisciplinary Research and Development, 4(9), 55-58.

Myers, D. G., \& Diener, E. (1995). Who is happy? Psychological Science, 6, 10-19. https://doi.org/10.1111/j.1467-9280.1995.tb00298.x

Near, J. P., Rice, R. W., \& Hunt, R. G. (1987). Job satisfaction and life satisfaction: A profile analysis. Social Indicators Research, 19, 383-401. https://doi.org/10.1007/BF00300728

O'Connor, K. E. (2008). "You choose to care": Teachers, emotions and professional identity. Teaching and Teacher Education, 24, 117-126. https://doi.org/10.1016/j.tate.2006.11.008

Ozer, M., \& Karabulut, O. O. (2003). Yaslilarda yasam doyumu. Geriatri Dergisi, 6(2), 72-74.

Paolini, L., Yanez, A. P. \& Kelly, W. E. (2006). An examination of worry and life satisfaction among college students. Individual Differences Research, 4(5), 331-339. 
Roffey, S. (2012). Pupil wellbeing - teacher wellbeing: two sides of the same coin? Educational ve Child Psychology, 29(4), 8-17.

Roth, G., Assor, A., Kanat-Maymon, Y., \& Kaplan, H. (2007). Autonomous motivation for teaching: How self-determined teaching may lead to self-determined learning. Journal of Educational Psychology, 99, 761-774. https://doi.org/10.1037/0022-0663.99.4.761

Sahin, S. (2008). Beden egitimi ogretmenlerinin tukenmislik ve yasam doyumu düzeyleri (Unpublished master thesis). Mersin Universitesi, Egitim Bilimleri Enstitusu, Mersin.

Skaalvik, E. M., \& Skaalvik, S. (2007). Dimensions of teacher selfefficacy and relations with strain factors, perceived collective teacher efficacy, and teacher burnout. Journal of Educational Psychology, 99, 611-625. https://doi.org/10.1037/0022-0663.99.3.611

Sucuoglu, B., \& Kuloglu, N. (1996). Ozurlu cocuklarla calisan ogretmenlerde tukenmisligin degerlendirilmesi. Turk Psikoloji Dergisi;C 11(36), 44-60.

Tsouloupas, C. N., Carson, R. L., Matthews, R., Grawitch, M. J., \& Barber, L. K. (2010). Exploring the association between teachers' perceived student misbehaviour and emotional exhaustion: The importance of teacher efficacy beliefs and emotion regulation. Educational Psychology, 30, 173-189. https://doi.org/10.1080/01443410903494460

Ucuncu, T. (2019). Istanbul ili Beylikduzu ilcesine bagli ilk ve ortaokullarda gorev yapmakta olan ogretmenlerde is ve yasam doyumunun degerlendirilmesi. Unpublished Public Health Thesis, Cerrahpasa Tip Fakultesi Halk Sagligi Anabilim Dali. Istanbul.

Van Veen, K., Sleegers, P., \& van de Ven, P. H. (2005). One teacher's identity, emotions, and commitment to change: A case study into the cognitive-affective processes of a secondary school teacher in the context of reforms. Teaching and Teacher Education, 21, 917-934. https://doi.org/10.1016/j.tate.2005.06.004

Veenhoven, R. (1991).Is Happiness relative? Social Indicators Research, 24, 1-34. https://doi.org/10.1007/BF00292648

Yilmaz, E., \& Sunbul, A, M. (2009). Ogretmenlerin yasam doyumlari ve okullardaki orgutsel guven duzeyi. Journal of Qafqaz University, 26, 172-179.

\section{Copyrights}

Copyright for this article is retained by the author(s), with first publication rights granted to the journal.

This is an open-access article distributed under the terms and conditions of the Creative Commons Attribution license which permits unrestricted use, distribution, and reproduction in any medium, provided the original work is properly cited. 